who was a member of this Society from 1840 till his death 1871, and is known as the author of numerous works, including the Traditions of Edinburgh, the History of the Rebellion, the Ancient Sea Margins, and the (anonymously published) Vestiges of Creation. William became a fellow of the Royal Society of Edinburgh in 1860; and he was made LL.D. by Edinburgh University in 1872. For his services to the cause of public instruction, and his work as a civic ruler, an offer of knighthood, which he declined, was made in 1881. But when, a fortnight before his death, a baronetcy was offered him, he accepted it. It had not, however, been formally conferred or gazetted, when on the 20th May 1883 he died, at the advanced age of more than 83 years, and but a few days before the ceremony that marked the completion of the last work of his life, the reopening of the "restored church of St Giles. He was buried in the place of his birth, and many manifestations were made of esteem and gratitude for his services to English-speaking men and women, by providing works of instruction and entertainment accessible at small cost to all of whatever rank or condition. His life of unremitting labour and his remarkable business abilities brought to him wealth, honour, and influence, and these were by him faithfully turned to account for the general good.

\title{
David Stevenson.
}

David Stevenson, the third son of the late Mr Robert Stevenson, the well-known civil engineer, was born at Edinburgh on the 11th January 1815. Educated at the High School and University of Edinburgh, he elected from the first to follow his father's profession. Before entering on his apprenticeship he was for some time in the workshops of one of the best millwrights of the day, where he acquired manipulative skill and the proper methods of working in different materials,-a course he always advocated for those who intended to follow the profession of civil engineering. After serving a regular pupilage under his father, during which period he had ample opportunities of attending various engineering works in progress, he was for some time engaged with Mr Mackenzie on 
railway works, particularly the Edgrehill Tunnel and the Liverpool and Manchester Railway. He gave a description of the "Liverpool and Manchester Railway" to the Royal Scottish Society of Arts in February 1835, and was awarded their medal for his exposition: This paper was followed, in March 1836, by "Remarks on the Dublin and Kingston Railway." In 1835 Brunel askęd Mr Stevenson to join his staff at the Thames Tunnel works,-an offer which he could not accept, as he had been appointed to superintend the construction of other works.

During the summer of the year 1837, $\mathrm{Mr}$ Stevenson made a tour in Canada and the United States, and the result of his inspection of the engineering works of these countries was given in a volume, published in 1838, entitled "Sketch of the Civil Engineering of North America," which was republished with additions in 1859, as one of Weale's series of engineering works. The engineering practice therein described was peculiarly applicable to newly developed countries, where timber forms the chief material employed. The views expressed and the drawings given in this book, with reference to the fine lines and speed of American river and lake steamers, were received in this country by shipbuilders with distrust, if not ridicule; but the bluff bows of British sea-going and river steamers, and short-stroke engines, all below deck, gave way to finer lines and engines of high power and long stroke; and soon thereafter steamships were plying on the Clyde at higher speed than in America. He had models made in New York of two of the fastest steamers, - $\mathrm{a}$ sea and river boat,- - which were submitted to the Admiralty after his book was published; but as the "lines" had been there given, the authorities did not care for the models, and they ultimately went to the Russian Government. In this book Mx Stevenson also pointed out the true conditions under which waves are formed, which his subsequent experience as a marine engineer amply corroborated.

Mr Stevenson entered into partnership with his father and brother Alan in 1838. As his father was then nearly 67 years of age, and his brother was wholly engaged with the arduous works at Skerryvore Lighthouse, the entire management of the business fell upon Mr Stevenson, and very soon his advice was much sought in reference to the improvement of rivers and harbours, and the con- 
struction of docks and other marine works. There are, indeed, very few rivers and harbours in Scotland with which he was not in some way professionally connected. He was also called upon to report or to execute works for the improvement of the rivers Dee, Lane, Ribble, and Wear in England; the Erne and Foyle in Ireland; and the Forth, Tay, Ness, Nith, and Clyde in Scotland. He designed and executed the works of restoration and enlargement of the Fossdyke in Lincolnshire,- - the oldest artificial navigation in Britain,-the widening and deepening being accomplished without stopping the traffic. His advice was also taken on many important questions relating to salmon fishings in rivers and estuaries, and in his Report of August 1842 on the Dornoch Fishings, he defined the different compartments of rivers, according to their physical characteristics, as "sea proper," "tidal," and "river proper." The views expressed in this report were subsequently treated at greater length in "Remarks on the Improvement of Tidal Rivers," communicated to this Society on 17th March 1845, which paper was afterwards published in a separate form by $M_{r}$ Weale. In this paper he stated his views with regard to the special works which should be undertaken for the improvement of the different compartments, and he showed conclusively that, if tidal propagation were accelerated, difference of level or height of head will be lessened and the velocity of the tide currents decreased; and the notion that, by deepening a river and removing obstructions, the water in it may be caused to rise higher and to endanger property on its banks, was without foundation. All his subsequent experience went to prove that the views expressed more than forty years ago were sound. He was also the first to enunciate the true theory of the origin of bars at the mouths of rivers, and to point out the works necessary for removing them and preventing their reformation. The necessity of having accurate data before designing works for the improvement of rivers, estuaries, and harbours led to his writing a treatise on the "Application of Marine Surveying and Hydrometry to the Practice of Civil Engineering." His known standing as a marine engineer led his old friend, the late $\mathrm{Mr}$ Adam Black, to invite him to write the article "Inland Navigation" for the last edition of the Encyclopcedia Britannica. This article was republished in 1858 as a separate treatise, entitled "Canal and 
River Engineering," and it is now in its third edition. In this book he has given the results of his practice in the treatment of rivers, and it will long remain the standard work in this difficult branch of engineering. In 1877 , at the request of the authorities, he delivered a course of four lectures on "Canal and River Engineering" to the students of the School of Military Engineering, Chatham.

During the height of the railway mania, when speculators were orerwhelming the Admiralty and Woods and Forests with schemes too numerous to be dealt with by the officials, Mr Sterenson was appointed to hold Courts of Inquiry, under the "Preliminary Inquiries Act," into the merits of a large number of railway and harbour projects and water-supply schemes, and in all cases save one his views were given effect to by the Authorities and Committees of Parliament. This exception was the proposed crossing of the Clyde by the Caledonian Railway. He reported that the railway might be allowed to cross the Clyde above Stockwell Bridge, but the Admiralty refused their sanction. A crossing, however, was subsequently applied for, and has been made.

In $1853 \mathrm{Mr}$ Stevenson succeeded his brother Alan as engineer to the Northern Lighthouse Board, and, along with his brother Thomas, who was at a subsequent date conjoined with him in the engineership, he designed and executed no fewer than twenty-eight beacons and thirty lighthouses, three of which-on North Unst, Dhu Heartach, and the Chickens Rocks-were works of great difficulty, requiring the exercise of great engineering skill. The advice of the firm was also taken by the Governments of India, Newfoundland, New Zealand, and Japan on lighthouse matters, and schemes for the lighting of the whole coasts of the two last countries were matured, and are now being carried out. In connection with the lighting of the coasts of Japan, where earthquakes are of frequent occurrence, $\mathrm{Mr}$ Stevenson devised the aseismatic arrangement, to mitigate the effect of shocks on the somewhat delicate apparatus used in lighthouses, and was awarded the Makdougall-Brisbane Medal of the Royal Scottish Society of Arts for his invention. Mr Stevenson took a great interest in the introduction of paraffin as an illuminant for lighthouses, instead of the more expensive colza oil. After experiments conducted at Edinburgh with the Doty burners, 
and actual trial during a month at Girdleness Lighthouse, a report was made to the Northern Lighthouse Board, embodying the following results:-That paraffin, as now manufactured, with a high specific gravity and flashing point, is safe; that the flame is of great purity and intensity, and easily maintained; the lamp glasses and lamps used for colza are equally suitable for paraffin; and that the initial power of the lights on the Scottish coasts would be exalted, and this, too, at an annual saving of $£ 3500$. The relative merits of colza oil and paraffin were thus settled, and most British and many European, foreign, and colonial lighthouses now consume paraffin, with an increased luminous intensity, and decreased cost of maintenance.

Mr Stevenson frequently appeared before Parliamentary Committees, and also gave evidence before Special Committees and Royal Commissions on Harbours, River Improvements, Harbours of Refuge and Lighthouses. For these Committees and Commissions he always prepared with scrupulous care; and he was a most conscientious witness, never entering the box without being satisfied as to the soundness of the cause he was supporting; and in no case did a Committee ever throw out a Bill, the Parliamentary plans and estimates of which he had prepared. In his native city $\mathrm{Mr}$ Stevenson was greatly respected, and his advice on many important matters connected with city improvements was sought and highly valued. His views on the eity improvement scheme, as conveyed to Lord Provost Chambers and the late Mr David Cousin, city architect, along with his letters which appeared in the Scotsman at the time, greatly facilitated the initiation of this great sanitary improvement, now nearing its completion. Among other local works, his firm designed and carried out the Edinburgh and Leith and North Leith sewerage schemes, and the widening of the North Bridge.

$\mathrm{Mr}$ Stevenson was consulting engineer to the Convention of Royal Burghs of Scotland and to the Highland and Agricultural Society. In the affairs of the latter he took a lively interest, especially in the trials of improved agricultural implements; and he contributed several papers and reports to their Transactions, notably one on the reclamation of land, and one on the relative merits of different systems of steam ploughing. The paper on "Reclamation 
and Protection of Agricultural Land" was republished as a separate treatise in 1874.

Mr Stevenson's books have taken a permanent place in engineering literature. Amid the exacting calls of his profession he found time to write many papers on engineering and cognate subjects, in addition to the books already noticed. He also wrote several articles for the last and the present editions of the Encyclopoedia Britannica, among which may be noticed "Canal," "Cofferdam," "Diving," and "Dredging." He was also the anthor of Our Lighthouses, being two articles written for his old friend, Dr Norman Macleod, while editor of Good Words, subsequently republished by Messrs Black, and of the Life of Robert Stevenson, published in 1878.

Mr Stevenson was twice elected President of the Royal Scottish Society of Arts, and for his Presidential Address of 1869 he chose as his subject "Altered Relations of British and Foreign Industries and Manufactures," in which he strongly urged the propriety of artisans improving their manipulative skill and their knowledge and management of the materials with which they had to deal, if they did not wish to be distanced in the race by foreign competition. He was elected a Fellow of this Society in 1844, and subsequently acted as a member of Council and one of its Vice-Presidents. In addition to the "Remarks on the Improvement of Tidal Rivers " already noticed, and several obituary notices of professional brethren, he contributed to our Proceedings "Notices of the Works designed by Sir C. A. Hartley for the Improvement of the Danube," "Notices of the Ravages of the Limnoria Terebrans on Creosoted Timber, and on Greenheart Timber." "Notice of Two Earthquakes on the West Coast of Scotland," and "Notice of Striated Rock Surfaces on North Berwick Law." He was elected a Member of the Institution of Civil Engineers in 1844, and acted as a member of its Council from 1877 till 1883, when he retired on account of ill-health; he was also a member of the Société des Ingénieurs Civils, Paris, and of other leamed Societies.

Mr Stevenson took a warm interest in the better endowment of the Chairs of the University of Edinburgh, and was mainly instrumental in founding the Glover Divinity Fellowship. He was a great lover of art in all its branches, and had formed a somewhat 
valuable collection of etchings and engravings, begun when a boy at the High School, his school companion in print-hunting being a life-long friend, Sir Theodore Martin. He was a man of sound judgment, unswerving rectitude, utterly devoid of ostentation, kind, open, and easily accessible. He was practically laid aside from work for about two years, and he died at North Berwick, on the 17 th July 1886, in the seventy-second year of his age.

\section{Bishop Cotterill. By Dr Cazenove.}

Henry Cotterill was born in the year 1812, on the 6th day of January, a day ecclesiastically known as the Feast of the Epiphany, and in popular parlance as Twelfth Night. $\mathrm{He}$ was the son of the Rev. Joseph Cotterill, rector of Blakeney, in the county of Norfolk. Mr Cotterill had been educated at Cambridge, and had taken a high degree, coming out as Seventh Wrangler. The grandfather of the future Bishop had also been a Cantabrigian, and was known in Sheffield as a man of culture. He was the author of a book of family prayers. All three were successively members of the same College. All three could say, with the poet Wordsworth,

"The Evangelist St John my patron was,"

and all could, with him, avow a fondness for mathematical as well as for classical studies.

In classics Henry Cotterill found a preceptress in his mother. This lady, known before her marriage as Miss Anne Boak, was very clever and clear-headed. She was a great friend of the celebrated Hannah More, and to some extent assisted that lady in the preparation of a tale, which was widely read at the time of its publication, Celebs in Search of a Wife. Miss Boak contributed some chapters which contained descriptions of scenery. She had also a considerable acquaintance with mathematics, and was generally a learned woman.

Not only did she superintend the education of her three daughters, but she instructed her two sons, Henry and George Cotterill, in Latin, until they were fifteen years of age.

Here, it will be said, is a clear case of heredity. I am far from 